Zeszyty Naukowe Szkoły Głównej Gospodarstwa Wiejskiego

Ekonomika i Organizacja Gospodarki Żywnościowej nr 116, 2016: 149-160

Ludwik Wicki

Katedra Ekonomiki i Organizacji Przedsiębiorstw

Szkoła Główna Gospodarstwa Wiejskiego w Warszawie

\title{
Zmiany produktywności czynników wytwórczych w polskim rolnictwie
}

\section{Wstęp}

Produktywność czynników wytwórczych jest jednym z ważniejszych zagadnień w ekonomii. Zwykle rozważa się produktywność poszczególnych czynników, do których zalicza się ziemię, pracę i kapitał. Równie ważnym aspektem jest ogólny wzrost zagregowanej produktywności wszystkich czynników, a także ustalanie znaczenia postępu technologicznego we wzroście produktywności. Począwszy od spostrzeżeń Schumpetera [1934], który twierdził, że postęp techniczny wynika z natury działań przedsiębiorców, a następnie prac Solowa [Solow 1957] w literaturze przedmiotu można zauważyć, że coraz większą uwagę zwraca się na to, że łączny wzrost produkcji przewyższa łączne zwiększenie zagregowanych nakładów. Od propozycji Solowa co do pomiaru zmian produktywności pojawiło się wiele modyfikacji. Tak zwana reszta Solowa dokładnie mierzy wzrost zagregowanej produktywności, gdy spełnione są dość restrykcyjne warunki dotyczące rodzaju funkcji produkcji, konkurencji doskonałej na rynku czynników produkcji oraz dokładności pomiaru. Późniejsze propozycje pełniejszego wyjaśnienia zmian produktywności w czasie i między krajami bazowały m.in. na powiązaniu ich $\mathrm{z}$ aktywnością w zakresie tworzenia innowacji [Comin i Gertler 2006]. Mechanizm osiągania większej produktywności zasobów w efekcie wprowadzanych innowacji przedstawiono na rysunku 1 . Wprowadzanie innowacji wiąże się zwykle z ponoszeniem dodatkowych kosztów $(\Delta \mathrm{K})$, ale uzyskiwany przyrost produkcji $(\Delta \mathrm{Q})$ jest więcej niż proporcjonalny, a więc koszt wytworzenia jednostki produktu obniża się. Należy pamiętać, że w przypadku popytu nieelastycznego na dany produkt prowadzi to także do spadku cen produktów na rynku. W takim przypadku może następować obniżenie utargu na jednostkę produktu, a w efekcie spadek dochodów producentów. 


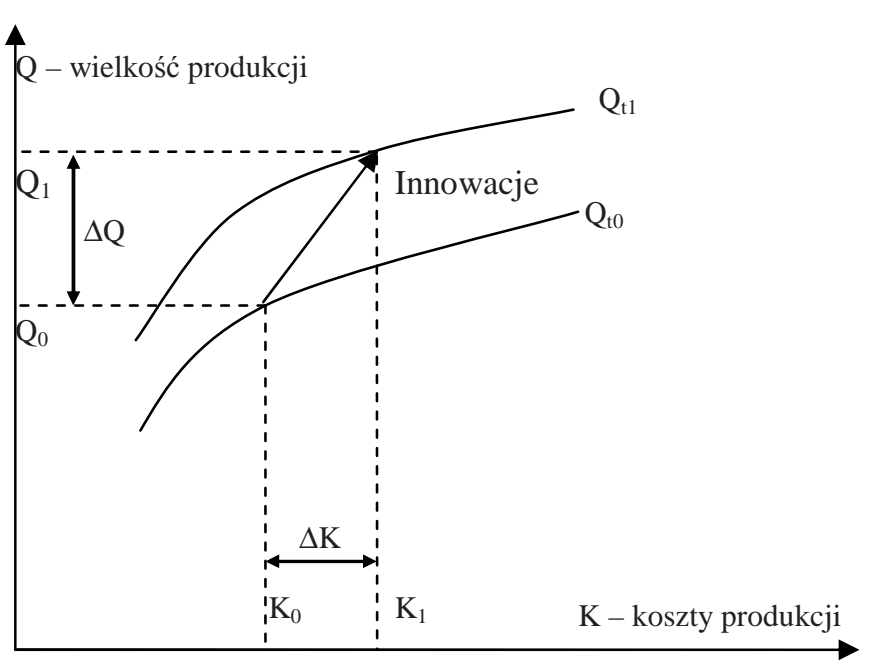

\section{Rysunek 1}

Przesunięcie funkcji produkcji dzięki inwestycjom związanym z wdrażaniem innowacji Źródło: Opracowanie własne.

Innym uwarunkowaniem uzyskiwania oczekiwanych efektów może być wzrost lub ograniczanie obrotów rynku danego produktu, np. z powodu wzrostu ogólnego popytu na rynku, pojawienia się substytutów, ale też nowego zastosowania dla produktu. Takim przykładem może być z jednej strony konkurencja między stosowaniem włókien naturalnych i syntetycznych w produkcji tkanin, a z drugiej wykorzystywanie produkcji rolniczej na biopaliwa (produkcja bioetanolu ze zbóż, biodiesla z rzepaku), co prowadzi do wzrostu popytu i cen [Wicki i Wicka 2016]. Nowe, inne niż tradycyjnie obserwowane, kierunki użycia produkcji rolniczej wynikają także z oczekiwania dostarczania różnych dóbr publicznych przez rolnictwo [Daniłowska 2015].

W odniesieniu do rolnictwa osiaganie ponadproporcjonalnego wzrostu produkcji jest dodatkowo komplikowane przez fakt, że większość wyników prac badawczo-rozwojowych dotyczących sektora pochodzi spoza niego. Dla osiagania postępu potrzebna jest dyfuzja technologii [Romer 1990]. Woś [1998] uważał, że w rolnictwie dominują właśnie zjawiska dyfuzji innowacji, a nie ewolucjonizmu. Zmiany produkcyjności zasobów mogą być także wyjaśniane na gruncie mechanizmu cenowego.

Działanie mechanizmu cenowego polegającego na oddziaływaniu zmian relacji cen między nakładami opisywane było przez wielu autorów [Rostow 1951, Heady 1967, Hayami i Ruttan 1969, Heijman i in. 1997]. Zmiana cen czynników wytwórczych wytrąca układ producenta z równowagi ekonomicznej, a w dalszej kolejności przyczyniasiędo tego, że powstaje noweoptimum producenta. Zależnie od tego, jaki czynnik drożeje, następuje zastępowanie go czynnikiem relatywnie 
tańszym. Zmiana relacji cen nakładów ukierunkowuje wybór techniki wytwarzania na taką, w której następuje oszczędzanie tych czynników, które są relatywnie drogie [Hicks 1932, Woś 1998]. Przykładowo wzrost kosztów pracy zachęca producentów do mechanizacji produkcji [Runowski i Maniecki 1997, Wicki 2012]. Ograniczeniem jest ryzyko wiążące się z zastosowaniem mało sprawdzonych w praktyce rozwiązań [Heijman i in. 1997]. Nie zawsze więc oszczędność drożejącego czynnika wytwórczego może być wystarczająco silnym motywem zmian, szczególnie w początkowym okresie po pojawieniu się innowacji umożliwiających wzrost produkcyjności.

Jedną z istotnych barier wprowadzania postępu i wzrostu produktywności czynników wytwórczych jest stabilny lub mały popyt na surowce żywnościowe i ich niskie ceny [Heijman i in. 1997, Weilandt 1997], szczególnie w warunkach nieelastycznego popytu [Heady 1967]. Wprowadzenie nowości może nie mieć istotnego wpływu na poziom dochodów producentów, gdyż wiąże się często z dużymi kosztami [Dudek i Wicki 2005]. Inne bariery wynikają z uwarunkowań społecznych. Przykładowo zmiany demograficzne prowadzące do wymiany pokoleniowej wśród kierowników gospodarstw są powolne, a więc nowe pokolenia rolników o lepszym przygotowaniu fachowym, w tym co do wprowadzania postępu w produkcji, nie są zaangażowane w podejmowanie decyzji. Innym ograniczeniem jest brak miejsc pracy poza rolnictwem, co skutkuje wysokim poziomem zatrudnienia w rolnictwie [Wicki i Grontkowska 2015] trwaniem małych gospodarstw, w których wprowadzanie postępu, szczególnie mechanizacyjnego, jest nieuzasadnione. Dodatkowe zasoby ziemi nie są uwalniane i dostępne dla efektywniejszych przedsiębiorstw, co pośrednio także ogranicza możliwości zwiększania efektywności poprzez lepsze wykorzystanie posiadanego przez nie wyposażenia.

Efekty wprowadzenia postępu technologicznego mogą pojawiać się z opóźnieniem wraz z opanowywaniem technologii przez rolników [Piggott i Marra 2008], co może zniechęcać innych do naśladownictwa i przyczynić się do spowolnienia procesu upowszechniania innowacji.

Ograniczenie uzyskiwania większej wydajności, szczególnie pracy, może wynikać ze zbyt małej skali produkcji w stosunku do pojawiających się nowych technologii umożliwiających ograniczenie pracochłonności procesów produkcji i niepodzielności środków technicznych. Inne ograniczenie to brak wiedzy. O ile koszty pozyskania wiedzy są często małe, to jej skuteczne zastosowanie może wymagać znacznych nakładów. Najczęstszym problemem jest brak odpowiednich kwalifikacji wśród rolników [Nordhaus 1976]. Dotyczy to zarówno wiedzy technologicznej, jak i technicznej oraz rynkowej.

Wzrost produkcyjności zasobów wynikający z postępu jest coraz ważniejszą składową w generowaniu wzrostu produkcji rolniczej. W skali globalnej 


\section{2}

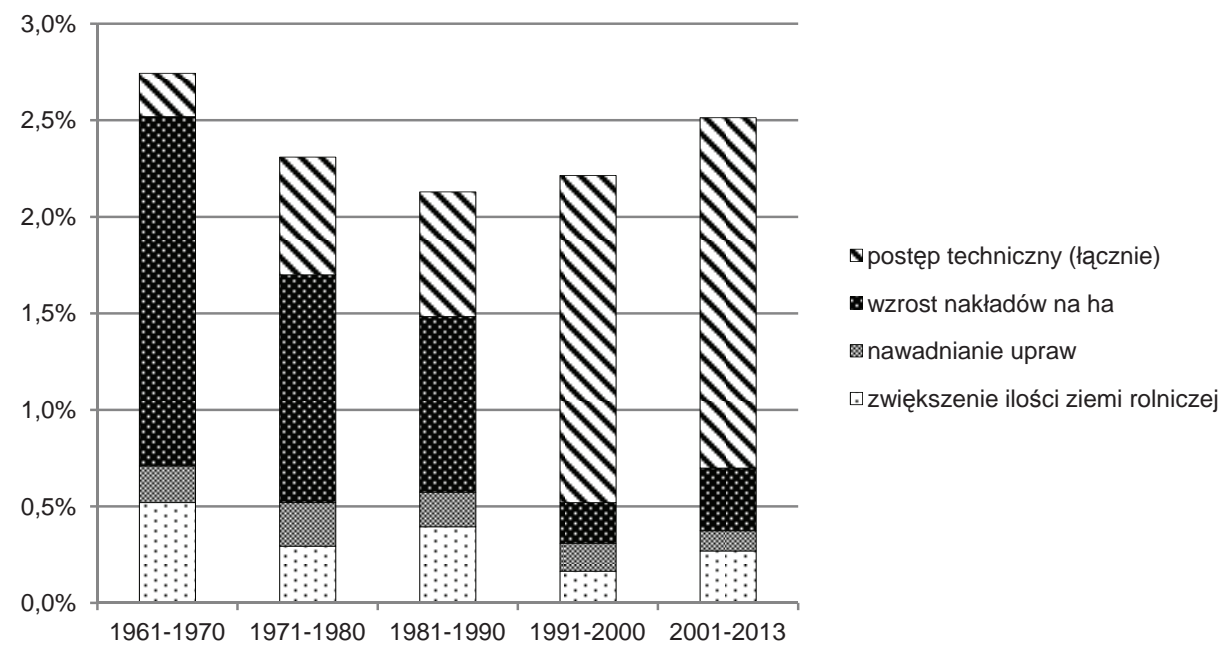

Rysunek 2

Struktura znaczenia głównych czynników we wzroście produkcji rolniczej na świecie w latach 1961-2013

Źródło: Fuglie i Rada [2013].

w latach 2001-2013 łączny jej wzrost wynosił około 2,5\% rocznie, z czego około 70\% przypisywano postępowi technicznemu (rys. 2). Od 1960 roku widoczny jest znaczny wzrost znaczenia postępu technicznego w ogólnym wzroście produkcji. W krajach rozwiniętych, w tym w USA, następuje wzrost produkcji mimo zmniejszenia nakładów czynników produkcji, takich jak ziemia, praca i kapitał trwały [Wang i in. 2015]. Spadek znaczenia tych czynników jest częściowo kompensowany zwiększonym zużyciem pośrednim środków do produkcji.

Uwzględniając przedstawione uwarunkowania, istotne staje się to, czy w polskim rolnictwie następuje poprawa produkcyjności czynników wytwórczych. Relatywnie większa dynamika wzrostu produkcyjności jednego czynnika względem innego może być podstawą do ustalenia kierunku zmian technologicznych. Ważne jest także tempo zmian.

Od 2004 roku dostępne stały się środki w ramach działań wspólnej polityki rolnej przeznaczane na modernizację rolnictwa, ale także na realizację działań ukierunkowanych na polepszenie struktury agrarnej. Znaczący napływ środków zmniejszył znaczenie ograniczenia w rozwoju wynikające z niedostatecznej kreacji kapitału w rolnictwie. Efekty podejmowanych działań powinny uwidocznić się już w postaci wzrostu efektywności wykorzystania czynnika pracy oraz (zapewne) kapitału. Wzrost inwestycji w rolnictwie prowadzi bowiem do wzrostu zasobów kapitału trwałego, podczas gdy zasoby pracy w rolnictwie pozostają na 
relatywnie stałym poziomie lub zmniejszają się. Uzyskane w pracy wyniki mogą być drobnym elementem oceny realizacji wspólnej polityki rolnej, szczególnie w obszarze efektów modernizacji rolnictwa. W związku z tym zaplanowano realizację badania rozpoznawczego dotyczącego dynamiki zmian produkcyjności podstawowych czynników produkcji. Należy pamiętać, że zakres pracy nie obejmuje zagregowanej oceny zmian produktywności czynników wytwórczych, ale analizę zmian produktywności brutto każdego z nich. Wynika to także z faktu, że z powodu trudności w uzyskaniu wiarygodnych i porównywalnych danych dotyczących zaplanowanego okresu analizy nie uwzględniono nakładów kapitału obrotowego. Nie można więc ocenić zmiany łącznej produktywności czynników.

\section{Cel i metodyka pracy}

Celem opracowania jest określenie poziomu i dynamiki zmian produktywności podstawowych czynników produkcji w polskim rolnictwie.

Osiągnięcie celu głównego nastąpiło poprzez realizację następujących zadań badawczych: (1) określenie poziomu produkcyjności ziemi, pracy i kapitału w ujęciu realnym w latach 1995-2015, (2) ustalenie i porównanie średniorocznej realnej dynamiki zmian produkcyjności ziemi, pracy i kapitału.

Dane do analizy pochodziły z GUS. Wykorzystano dane dotyczące poziomu produkcji globalnej i towarowej rolnictwa, powierzchni użytków rolnych, liczby pracujących w rolnictwie, wartości środków trwałych, wskaźników cen produkcji globalnej i towarowej w rolnictwie. Dla czynnika praca okres analizy skrócono do lat 2000-2015, gdyż tylko dla tego zakresu czasowego uzyskano porównywane dane dotyczące nakładów pracy w rolnictwie.

Pod uwagę wzięto trzy czynniki: ziemię, pracę i środki trwałe. Po stronie produkcji uwzględniono realną wartość produkcji globalnej i towarowej. Wartość nominalną produkcji globalnej i towarowej w rolnictwie przeliczono na wartości realne z wykorzystaniem wskaźników cen produkcji globalnej i towarowej w rolnictwie. Za podstawę odniesienia przyjęto ceny z 2015 roku. Średnioroczną dynamikę zmian ustalono na podstawie funkcji regresji, przyjmując wykładniczą postać funkcji, w której zmienną zależną $(Y)$ była produkcyjność jednostkowa, zmienną niezależną czas $(t)$. Zmiana średnioroczna jest równa parametrowi $B$ w funkcji ln $(Y)=A+B t$. Dopasowanie przebiegu funkcji do danych rzeczywistych określono na postawie współczynnika determinacji $\left(\mathrm{R}^{2}\right)$ dla uzyskanego modelu funkcji. Istotność współczynnika kierunkowego określono na podstawie 95-procentowego przedziału ufności. 


\section{Wyniki badań}

Powierzchnia użytków rolnych (UR) w Polsce w badanym okresie zmniejszała się. W 1995 roku było $18 \mathrm{mln}$ ha, a w 2015 roku już tylko 14,5 mln ha. Podobnie pewnym zmianom ulegała liczba pracujących w rolnictwie, $\mathrm{z}$ tym, że od 2000 roku nie notuje się wyraźnych zmian. Wartość środków trwałych wykorzystywanych w rolnictwie zwiększała się (tab. 1). W 2000 roku nastąpi-

Tabela 1

Zasoby czynników i wartość produkcji w polskim rolnictwie w latach 1995-2015

\begin{tabular}{|c|c|c|c|c|c|}
\hline \multirow{2}{*}{ Lata } & \multirow{2}{*}{$\begin{array}{l}\text { Powierzchnia } \\
\text { UR [mln ha] }\end{array}$} & \multirow{2}{*}{$\begin{array}{c}\text { Liczba } \\
\text { pracujących } \\
\text { w rolnictwie } \\
\text { [tys.] }\end{array}$} & \multirow{2}{*}{$\begin{array}{l}\text { Wartość } \\
\text { środków } \\
\text { trwałych } \\
\text { [mld PLN] }\end{array}$} & $\begin{array}{l}\text { Produkcja } \\
\text { globalna }\end{array}$ & $\begin{array}{l}\text { Produkcja } \\
\text { towarowa }\end{array}$ \\
\hline & & & & \multicolumn{2}{|c|}{$\begin{array}{c}\text { ceny stałe z } 2005 \text { r. } \\
{[\mathrm{mld} \text { PLN] }}\end{array}$} \\
\hline 1995 & 17,93 & 4125,3 & 110,8 & 82,7 & 44,0 \\
\hline 1996 & 17,88 & 4293,0 & 108,9 & 83,3 & 46,3 \\
\hline 1997 & 17,83 & 4300,8 & 109,1 & 83,1 & 46,9 \\
\hline 1998 & 17,84 & 4281,0 & 109,3 & 88,0 & 49,4 \\
\hline 1999 & 17,82 & 4259,8 & 109,1 & 83,2 & 49,6 \\
\hline 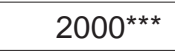 & 17,80 & 2091,7 & 109,1 & 79,2 & 48,3 \\
\hline 2001 & 17,74 & 2088,2 & 109,7 & 83,8 & 49,7 \\
\hline 2002 & 16,90 & 2091,1 & 110,5 & 82,1 & 51,7 \\
\hline 2003 & 16,17 & 2073,8 & 110,8 & 81,5 & 54,4 \\
\hline 2004 & 16,33 & 2080,3 & 111,0 & 87,5 & 56,2 \\
\hline 2005 & 15,91 & 2070,4 & 112,4 & 88,5 & 58,3 \\
\hline 2006 & 15,96 & 2070,8 & 114,7 & 87,5 & 60,7 \\
\hline 2007 & 16,18 & 2069,2 & 117,4 & 92,9 & 61,8 \\
\hline 2008 & 16,15 & 2063,5 & 119,7 & 95,6 & 65,5 \\
\hline 2009 & 16,12 & 2061,4 & 122,6 & 98,2 & 68,3 \\
\hline 2010 & 15,50 & 2326,2 & 124,3 & 95,4 & 66,4 \\
\hline 2011 & 15,44 & 2325,6 & 135,5 & 97,4 & 68,9 \\
\hline 2012 & 15,05 & 2325,7 & 130,4 & 96,6 & 69,7 \\
\hline 2013 & 14,41 & 2326,7 & 134,0 & 99,8 & 73,0 \\
\hline 2014 & 14,56 & 2331,5 & 137,4 & 105,2 & 74,6 \\
\hline 2015 & 14,55 & 2331,3 & 139,7 & 98,3 & 74,5 \\
\hline \multicolumn{6}{|c|}{ Zmiana średnioroczna [\%]* } \\
\hline$x$ & $-1,16$ & $0,97^{\star \star}$ & 1,31 & 1,19 & 2,78 \\
\hline
\end{tabular}

* W okresie 1995-2015, ** w okresie 2000-2015, ***od 2000 roku nastapiła zmiana definicji pracującego w rolnictwie.

Źródło: Dane GUS oraz obliczenia własne. 
ła zmiana definicji pracującego w rolnictwie i przedstawiana przez GUS liczba pracujących w rolnictwie zmniejszyła się o 50\%. Należy zwrócić uwagę na to, że na podstawie spisu rolnego przeprowadzonego w 2010 roku ustalono większą niż w latach wcześniejszych liczbę pracujących w rolnictwie. W związku z tym zmiany wydajności pracy obserwowane w latach 2000-2009 i 2010-2015 należy ujmować oddzielnie.

Jak wspomniano wcześniej, według danych GUS od 1995 roku do 2015 roku z użytkowania rolniczego wyłączono prawie $3,4 \mathrm{mln}$ ha. Spadek powierzchni UR wynosił $1,16 \%$ średniorocznie. Należy dodać, że zmiana powierzchni wynikała w pewnej części ze zmiany definicji użytków rolnych, co może być przyczyną przeszacowania zmian produkcyjności ziemi w prowadzonej analizie.

Inaczej niż w przypadku zasobów ziemi kształtowały się zmiany liczby pracujących w rolnictwie oraz wartości środków trwałych. Liczba pracujących w rolnictwie wzrastała w latach 2000-2015 o 0,97\% średniorocznie, a wartość środków trwałych zwiększała się w okresie 1995-2015 o 1,31\% średniorocznie. Oznacza to, że zmniejszaniu zasobów ziemi towarzyszył wzrost zasobów kapitału trwałego i ziemi, a więc obserwowano intensyfikację produkcji. Podobnie jak w odniesieniu do zasobów ziemi uwagi odnośnie podawanych wielkości należy odnieść do liczby pracujących w rolnictwie. Po 2010 roku podawana przez GUS liczba pracujących skokowo wzrosła w związku z uzyskanymi wynikami spisu rolnego. Ze względu na to potrzebne było wydzielenie podokresów w ocenie zmian produkcyjności pracy.

Produkcja globalna zwiększała się w okresie 1995-2015 o 1,19\% średniorocznie, a produkcja towarowa o 2,78\% średniorocznie. Dynamika zmian produkcji była więc większa niż dynamika nakładów. Produkcja globalna wzrosła realnie o $18 \%$, a produkcja towarowa o 53\%. Większa dynamika produkcji towarowej niż globalnej skutkowała wzrostem towarowości rolnictwa z $56 \%$ w latach 1995-1999 do 76\% w okresie 2011-2015.

Wzrost towarowości produkcji rolniczej może wynikać z dychotomicznego modelu rozwoju polskiego rolnictwa. $\mathrm{Z}$ jednej strony istnieje duża liczba małych, niskotowarowych gospodarstw rolnych pełniących funkcje socjalne lub rezydencjonalne, a z drugiej strony zwiększa się znaczenie gospodarstw większych obszarowo i ekonomicznie, nastawionych na produkcję towarowa. Według Gołębiewskiej [2010] takie gospodarstwa rozwijają się szybciej niż te o słabych związkach z rynkiem. W 2015 roku ponad $60 \%$ produkcji towarowej rolnictwa było wytwarzane przez około 200 tys. gospodarstw o powierzchni powyżej 15 ha UR (15\% ogółu). Należy więc także wskazać na zmiany strukturalne w rolnictwie jako czynnik wzrostu jego produkcyjności. Analiza tej zależności wychodzi jednak poza założone ramy niniejszego opracowania. 


\section{6}

Tabela 2

Zmiany poziomu produkcyjności podstawowych czynników produkcji w polskim rolnictwie w latach 1995-2015

\begin{tabular}{|c|c|c|c|c|c|c|}
\hline \multirow[b]{2}{*}{ Wyszczególnienie } & \multicolumn{3}{|c|}{$\begin{array}{c}\text { Produkcja globalna } \\
\text { (ceny stałe z } 2005 \text { r.) [PLN] }\end{array}$} & \multicolumn{3}{|c|}{$\begin{array}{c}\text { Produkcja towarowa } \\
\text { (ceny stałe z } 2005 \text { r.) [PLN] }\end{array}$} \\
\hline & $\begin{array}{l}\text { na } 1 \text { ha } \\
\text { UR }\end{array}$ & $\begin{array}{l}\text { na } 1 \text { pracu- } \\
\text { jącego }\end{array}$ & $\begin{array}{l}\text { na } 1 \text { PLN } \\
\text { środków } \\
\text { trwałych }\end{array}$ & $\begin{array}{l}\text { na } 1 \text { ha } \\
\text { UR }\end{array}$ & $\begin{array}{l}\text { na } 1 \text { pracu- } \\
\text { jącego }\end{array}$ & $\begin{array}{l}\text { na } 1 \text { PLN } \\
\text { środków } \\
\text { trwałych }\end{array}$ \\
\hline 1995 & 4609,8 & * & 0,75 & 2451 & * & 0,40 \\
\hline 1996 & 4656,6 & * & 0,76 & 2590 & * & 0,43 \\
\hline 1997 & 4662,3 & * & 0,76 & 2629 & * & 0,43 \\
\hline 1998 & 4933,7 & * & 0,81 & 2768 & * & 0,45 \\
\hline 1999 & 4672,3 & * & 0,76 & 2785 & * & 0,45 \\
\hline 2000 & 4448,0 & 37,8 & 0,73 & 2712 & 23,1 & 0,44 \\
\hline 2001 & 4722,8 & 40,1 & 0,76 & 2799 & 23,8 & 0,45 \\
\hline 2002 & 4861,0 & 39,3 & 0,74 & 3061 & 24,7 & 0,47 \\
\hline 2003 & 5040,5 & 39,3 & 0,74 & 3366 & 26,2 & 0,49 \\
\hline 2004 & 5358,7 & 42,1 & 0,79 & 3441 & 27,0 & 0,51 \\
\hline 2005 & 5566,1 & 42,8 & 0,79 & 3667 & 28,2 & 0,52 \\
\hline 2006 & 5481,9 & 42,2 & 0,76 & 3807 & 29,3 & 0,53 \\
\hline 2007 & 5741,9 & 44,9 & 0,79 & 3818 & 29,8 & 0,53 \\
\hline 2008 & 5917,4 & 46,3 & 0,80 & 4054 & 31,7 & 0,55 \\
\hline 2009 & 6081,1 & 47,7 & 0,80 & 4230 & 33,1 & 0,56 \\
\hline 2010 & 6151,8 & 41,0 & 0,77 & 4285 & 28,6 & 0,53 \\
\hline 2011 & 6306,3 & 41,9 & 0,72 & 4464 & 29,6 & 0,51 \\
\hline 2012 & 6415,7 & 41,5 & 0,74 & 4633 & 30,0 & 0,53 \\
\hline 2013 & 6922,7 & 42,9 & 0,74 & 5066 & 31,4 & 0,54 \\
\hline 2014 & 7228,8 & 45,1 & 0,77 & 5121 & 32,0 & 0,54 \\
\hline 2015 & 6756,5 & 42,2 & 0,70 & 5123 & 32,0 & 0,53 \\
\hline $\begin{array}{l}\text { Zmiana } \\
1995-2015 \\
(1995=100) \\
\end{array}$ & 147 & 111 & 94 & 209 & 138 & 134 \\
\hline \multirow{2}{*}{$\begin{array}{l}\text { Dynamika } \\
\text { średnioroczna } \\
\text { [\%] }\end{array}$} & \multirow{2}{*}{2,35} & $2,41^{\star \star}$ & \multirow[b]{2}{*}{$-0,12$} & \multirow[b]{2}{*}{3,94} & 4,00 ** & \multirow[b]{2}{*}{1,47} \\
\hline & & $1,13^{\star \star *}$ & & & 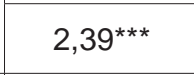 & \\
\hline $\begin{array}{l}\text { Przedział ufności } \\
95 \%\end{array}$ & $\begin{array}{l}2,03- \\
-2,67 \\
\end{array}$ & $\begin{array}{l}1,69-3,16^{* *} \\
-2,5-4,4^{* * *}\end{array}$ & $-0,40-0,16$ & $\begin{array}{l}3,68- \\
-4,19 \\
\end{array}$ & $\begin{array}{l}3,73-4,32^{\star *} \\
0,81-3,50^{\star * *}\end{array}$ & $1,15-1,80$ \\
\hline \multirow{2}{*}{$\begin{array}{l}\text { Współczynnik } \\
\text { determinacji }\left(\mathrm{R}^{2}\right) \\
{[\%]}\end{array}$} & \multirow[b]{2}{*}{92,6} & $89,7^{* \star}$ & \multirow[b]{2}{*}{3,9} & \multirow[b]{2}{*}{98,2} & $99,3^{\star \star}$ & \multirow[b]{2}{*}{82,6} \\
\hline & & $89,6^{\star \star \star}$ & & & $21,2^{\star \star \star}$ & \\
\hline
\end{tabular}

*za lata 1995-1999 dane nieporównywalne, **dla okresu 2000-2009, ***dla okresu 2010-2015. Źródło: Obliczenia własne. 
Na podstawie danych zestawionych w tabeli 1 ustalono poziom rolniczej produkcji globalnej i towarowej w przeliczeniu na 1 ha UR, na 1 pracującego oraz na 1 PLN wartości środków trwałych. Wyniki przedstawiono w tabeli 2.

Podsumowując, w polskim rolnictwie w latach 1995-2015 następował znaczący wzrost produkcyjności czynników wytwórczych. Najszybszy wzrost zaobserwowano w zakresie produkcyjności ziemi, kolejno pracy i kapitału. Wynika z tego, że realizowany w polskim rolnictwie proces rozwoju wiąże się z postępem ziemio- i pracooszczędnym. Ziemia i praca są substytuowane kapitałem, co szczególnie wyraźne stało się po 2004 roku, a więc po integracji Polski z UE i wprowadzeniem mechanizmów wspólnej polityki rolnej, w tym wsparcia inwestycji. W przyszłości należy oczekiwać istotnego wzrostu produkcyjności pracy wynikającego ze zmian w strukturze gospodarstw rolnych i zmniejszania się liczby pracujących $\mathrm{w}$ rolnictwie oraz $\mathrm{z}$ dalszego zwiększania znaczenia gospodarstw większych obszarowo i ekonomicznie.

\section{Podsumowanie}

Wzrost produkcji rolniczej może być realizowany poprzez zwiększanie nakładów czynników produkcji, ale także poprzez wprowadzanie postępu technologicznego w rolnictwie. Od połowy XX wieku w kolejnych okresach wyraźna staje się kluczowa rola postępu w kreowaniu wzrostu produkcji. Na świecie po 2000 roku aż $72 \%$ wzrostu produkcji rolniczej wynikało ze zwiększenia efektywności wykorzystania nakładów utożsamianego z postępem, a tylko $28 \%$ było efektem wzrostu nakładów.

W latach 1995-2015 w polskim rolnictwie następował znaczący przyrost produkcyjności czynników wytwórczych. Wynosił on, mierząc wartością produkcji towarowej: $100 \%$ dla ziemi, $38 \%$ dla pracy i $34 \%$ dla kapitału. Średnioroczna stopa wzrostu wynosiła odpowiednio: 3,94, 2,39 i 1,34\%. Najszybciej następował wzrost produkcyjności ziemi, a kierunek zmian wskazuje na kapitałochłonny oraz ziemio- i pracooszczędny kierunek zmian technik wytwórczych w polskim rolnictwie.

Obserwowane tempo zmian wydajności czynników wytwórczych, szczególnie pracy, jest mniejsze od oczekiwanego. W ostatnim dziesięcioleciu dynamika produkcyjności pracy $\mathrm{w}$ rolnictwie $\mathrm{w}$ wielu krajach UE była większa, co prowadzi do zwiększania luki wydajności, ale też będzie czynnikiem zmniejszającym konkurencyjność polskiego rolnictwa. Jako pozytywne zjawisko należy postrzegać znaczący wzrost wydajności ziemi. Dynamika wzrostu produkcyjności pracy będzie zależeć przede wszystkim od zmian w strukturze obszaro- 
wej gospodarstw i koncentracji ziemi oraz produkcji w dużych gospodarstwach towarowych.

Przedstawione opracowanie ma kilka istotnych ograniczeń. Najważniejszym z nich jest zastosowane ujęcie nakładów kapitału w rolnictwie, w tym brak wydzielenia nakładów obrotowych środków produkcji. Efektem może być zbyt wysokie oszacowanie dynamiki produkcyjności kapitału. $\mathrm{Z}$ tego powodu nie określono także wskaźnika TFP. Nie objęto także odrębną analizą poszczególnych sektorów rolnictwa, które mogą charakteryzować się zróżnicowaną dynamiką zmian. Ze względu na trudność osiaggnięcia porównywalności danych nie przedstawiono odniesienia do sytuacji w innych krajach. Dalsze badania powinny być prowadzone zarówno w kierunku porównania między wyspecjalizowanymi sektorami rolnictwa, jak i między krajami.

\section{Literatura}

COMIN D., GERTLER M., 2006: Medium Term Business Cycles, American Economic Review 96, 523-551.

DANIŁOWSKA A., 2015: Provision of Public Goods by Agriculture in Poland, Economic Science for Rural Development 37, 142-151.

DUDEK H., WICKI L., 2005: Wpływ podstawowych nakładów plonotwórczych na poziom i wartość produkcji w gospodarstwach rolniczych, Roczniki Nauk Rolniczych Seria G (92) 1, 30-41.

FUGLIE K., RADA N., 2013: Growth in Global Agricultural Productivity: An Update, Economic Research Service, USDA [https://www.ers.usda.gov/amber-waves/2013/november/growth-in-global-agricultural-productivity-an-update].

GOŁĘBIEWSKA B., 2010: Organizacyjno-ekonomiczne skutki zróżnicowania powiqzań gospodarstw rolniczych z otoczeniem, Wydawnictwo SGGW, Warszawa.

HAYAMI Y., RUTTAN V., 1969: Factor Prices and Technical Change in Agricultural Development: The United States and Japan, University of Minnesota. P69-19, St. Paul.

HEADY E., 1967: Ekonomika produkcji rolniczej, PWRiL, Warszawa.

HEIJMAN W., KRZYŻANOWSKA Z., GĘDEK S., KOWALSKI Z., 1997: Ekonomika rolnictwa. Zarys teorii, Wydawnictwo Fundacja „Rozwój SGGW”, Warszawa.

HICKS J., 1932: The Theory of Wages, Macmillan, London.

NORDHAUS W., 1976: Innowacje, wzrost i dobrobyt. Postęp techniczny w ujęciu ekonomicznym, PWN, Warszawa.

PIGGOTT N., MARRA M., 2008: Biotechnology Adoption Over Time in the Presence of Non-Pecuniary Characteristics that Directly Affect Utility: A Derived Demand Approach, AgBioForum 11 (1), 58-70.

ROMER, P., 1990: Endogenous Technical Change, Journal of Political Economy 98, 71-102.

ROSTOW W., 1951: Some Notes on Mr. Hicks and History, The American Economic Review 41 (3), 316-324. 
RUNOWSKI H., MANIECKI F., 1997: Zmiany w technologiach chowu bydla mlecznego (na przykładzie krajów zachodnioeuropejskich). [w:] F. Maniecki (red.), Postęp techniczny a organizacja gospodarstw rolniczych, Wydawnictwo SGGW, Warszawa, 141-164.

SCHUMPETER J., 1934: The Theory of Economic Development, Oxford University Press, Oxford.

SOLOW R., 1957: Technical Change and the Aggregate Production Function, Review of Economics and Statistics 39, 312-320.

WANG S., HEISEY P., SCHIMMELPFENNIG D., BALL E., 2015: U.S. Agricultural Productivity Growth: The Past, Challenges, and the Future, ERS USDA.

WEILANDT A., 1997: Sprawność przemysłowej technologii produkcji drobiarskiej, [w:] F. Maniecki (red.), Postęp techniczny a organizacja gospodarstw rolniczych, Wydawnictwo SGGW, Warszawa, 165-184.

WICKI L., 2012: Convergence of Labour Productivity in Agriculture in the European Union. Economic Science for Rural Development 27, 279-284.

WICKI L., DUDEK H., 2005: Wpływ podstawowych nakładów plonotwórczych na poziom i wartość produkcji w gospodarstwach rolniczych, Roczniki Nauk Rolniczych Seria G 92, 1, 30-41.

WICKI L., GRONTKOWSKA A., 2015: Zmiany znaczenia agrobiznesu w gospodarce i w jego wewnętrznej strukturze, Roczniki Naukowe Ekonomii Rolnictwa i Obszarów Wiejskich 102 3, 21-32.

WICKI L., WICKA A., 2016: Bio-Economy Sector in Poland and Its Importance in the Economy, Economic Science for Rural Development 41, 219-228.

WOŚ A., 1998: Postęp w agrobiznesie, [w:] Encyklopedia agrobiznesu, Fundacja Innowacja, Warszawa, 581-587.

\section{Changes in factor productivity in Polish agriculture}

\section{Abstract}

The aim of the study is to determine the level and dynamics of changes in the productivity of the basic production factors in Polish agriculture for the years 1995-2015. The analysis was conducted on the basis of statistical data provided by the Central Statistical Office. Changes in the productivity of land, labour and capital were determined separately. There was a significant increase in the productivity of the basic production factors in Polish agriculture. Based on the value of commercial production as a measure, it was found that in the years 1995-2015 the land productivity has increased by 100\%, labour productivity by $38 \%$ and capital productivity by $34 \%$. The compound annual growth rates were amounted to 3.94, 2.39 and 1.34\% respectively. Based on the research results one can say that technological changes in Polish agriculture are relatively land-saving and capital-intensive. The productivity growth in agriculture in the future 
will depend mainly on the dynamics of land concentration in larger farms and consequently increase of the production scale in agriculture.

Key words: technological change, productivity, agriculture, production factors, land, labour, capital 